\title{
Freshwater temperature in the state of Rio Grande do Sul, Southern Brazil, and its implication for fish culture
}

\author{
Luciano de Oliveira Garcia ${ }^{1}$, Carlos Eduardo Copatti ${ }^{1}$, Flávio Wachholz², \\ Waterloo Pereira Filho ${ }^{2}$ and Bernardo Baldisserotto ${ }^{1}$
}

In this study we verified data of water temperatures collected by CORSAN-RS from 1996 to 2004 in several cities of the state of Rio Grande do Sul, southern Brazil, and analyzed the possibility of raising the most cultivated fish species in Brazil. The water temperature from 1996 to 2004 was 16 to $28^{\circ} \mathrm{C}$ in summer, 17 to $23^{\circ} \mathrm{C}$ in fall, 14 to $17^{\circ} \mathrm{C}$ (down to $9^{\circ} \mathrm{C}$ in the coldest months) in winter and 14 to $21^{\circ} \mathrm{C}$ in spring. Native species of this state, such as silver catfish (Rhamdia quelen), traíra (Hoplias malabaricus), dorado (Salminus brasiliensis), pintado (Pimelodus maculatus), as well as carps (family Cyprinidae), are resistant to the low winter temperatures. These species have a lower growth rate in coldest months (winter/spring) but a good development in warmer months (summer/fall), reaching a satisfactory performance throughout the year. In the periods of more intense cold, mortality of some introduced species, such as surubim from Amazon Basin (Pseudoplatystoma sp.), pirapitinga (Piaractus brachypomus), pirarucu (Arapaimas gigas), pacu (Piaractus mesopotamicus), tambaqui (Colossoma macropomum) and Nile tilapia (Oreochromis niloticus) may occur. In addition, as most tropical species have a thermal range for growth and reproduction between 20 to $28^{\circ} \mathrm{C}$, some species may have poor development even in fall. Therefore, water temperature in this state should be considered in the choice of fish species to be cultivated.

Neste estudo verificaram-se dados de temperaturas de água coletados pela CORSAN-RS de 1996 a 2004, em várias cidades do estado do Rio Grande Sul, sul do Brasil, e analisou-se a possibilidade de criação das principais espécies de peixe cultivadas no Brasil. A temperatura da água de 1996 a 2004 foi de 16 a $28^{\circ} \mathrm{C}$ no verão, de 17 a $25^{\circ} \mathrm{C}$ no outono, 14 a $17^{\circ} \mathrm{C}$ (chegando a $9^{\circ} \mathrm{C}$ nos meses mais frios) no inverno e 14 a $21^{\circ} \mathrm{C}$ na primavera. Espécies nativas deste estado, como o jundiá (Rhamdia quelen), traíra (Hoplias malabaricus), dourado (Salminus brasiliensis), pintado (Pimelodus maculatus), assim como as carpas (família Cyprinidae), são resistentes às baixas temperaturas do inverno. Estas espécies apresentam uma menor taxa de crescimento nos meses mais frios (inverno/primavera), mas um bom desenvolvimento em meses mais quentes (verão/outono), alcançando um desempenho satisfatório durante o ano. Nos períodos de frios mais intensos pode ocorrer uma intensa mortalidade de algumas espécies introduzidas, como o surubim da Bacia Amazônica (Pseudoplatystoma sp.), pirapitinga (Piaractus brachypomus), pirarucu (Arapaimas gigas), pacu (Piaractus mesopotamicus), tambaqui (Colossoma macropomum) e tilápia nilótica (Oreochromis niloticus). Além disso, como a maioria das espécies tropicais apresenta sua faixa térmica para crescimento e reprodução entre 20 a $28^{\circ} \mathrm{C}$, algumas espécies podem ter um baixo desenvolvimento também no outono. Portanto, a temperatura da água deste estado deve ser considerada na escolha das espécies de peixes a serem cultivadas.

Key words: Fish growth, Mortality, growth, Freshwater fish, Water temperature.

\section{Introduction}

The culture of freshwater fish in Brazil was continuously increasing up to 2001, but during 2002-2004 there was almost no increase in production. However, in the south region and Rio Grande do Sul state the latest data presented a stagnation pattern with even a tendency towards decreased production in 2005-2006 (Baldisserotto, in prep.).
Temperature limits a great variety of biological processes, from the speed of simple reactions to the ecological distribution of fish species (Arana, 2004). Most fishes are ectothermic, with their body temperatures being determined by water temperature (Hazel, 1993). Consequently, this parameter can also interfere with fish growth and feeding rate (Laevastu \& Hayes, 1984), and significant changes in water temperature may cause a serious challenge to the maintenance of physi-

${ }^{1}$ Departamento de Fisiologia e Farmacologia, Universidade Federal de Santa Maria, 97105-900 Santa Maria, RS, Brazil.

2Departamento de Geociências, Universidade Federal de Santa Maria, 97105.900 Santa Maria, RS, Brazil. 
ological function (Hazel, 1993). Different fish species possess different ranges of temperature preference (Baldisserotto, 2002). Thus, to improve productivity or simply identify which species should be cultivated in a certain environment it is important to know the water temperature range in the area. Therefore, the objective of this study was to analyze the mean freshwater temperatures from 1996 to 2004 in the state of Rio Grande do Sul, southern Brazil, collected by a state agency, and to relate it to the culture of fish species in Brazil proposed for cultivation.

\section{Material and Methods}

The Companhia Riograndense de Saneamento (CORSANRS) measures the water temperature in their water treatment stations (WTS) on a daily basis in all the state of Rio Grande do Sul, Brazil. The collection of data was made using graduate glass thermometers submerged into the water as it arrived in the WTS, pumped from rivers or lakes. Mean monthly data collected in the WTS for nine years (1996 to 2004) of several cities of this state (Alegrete, Alvorada, Bento Gonçalves,
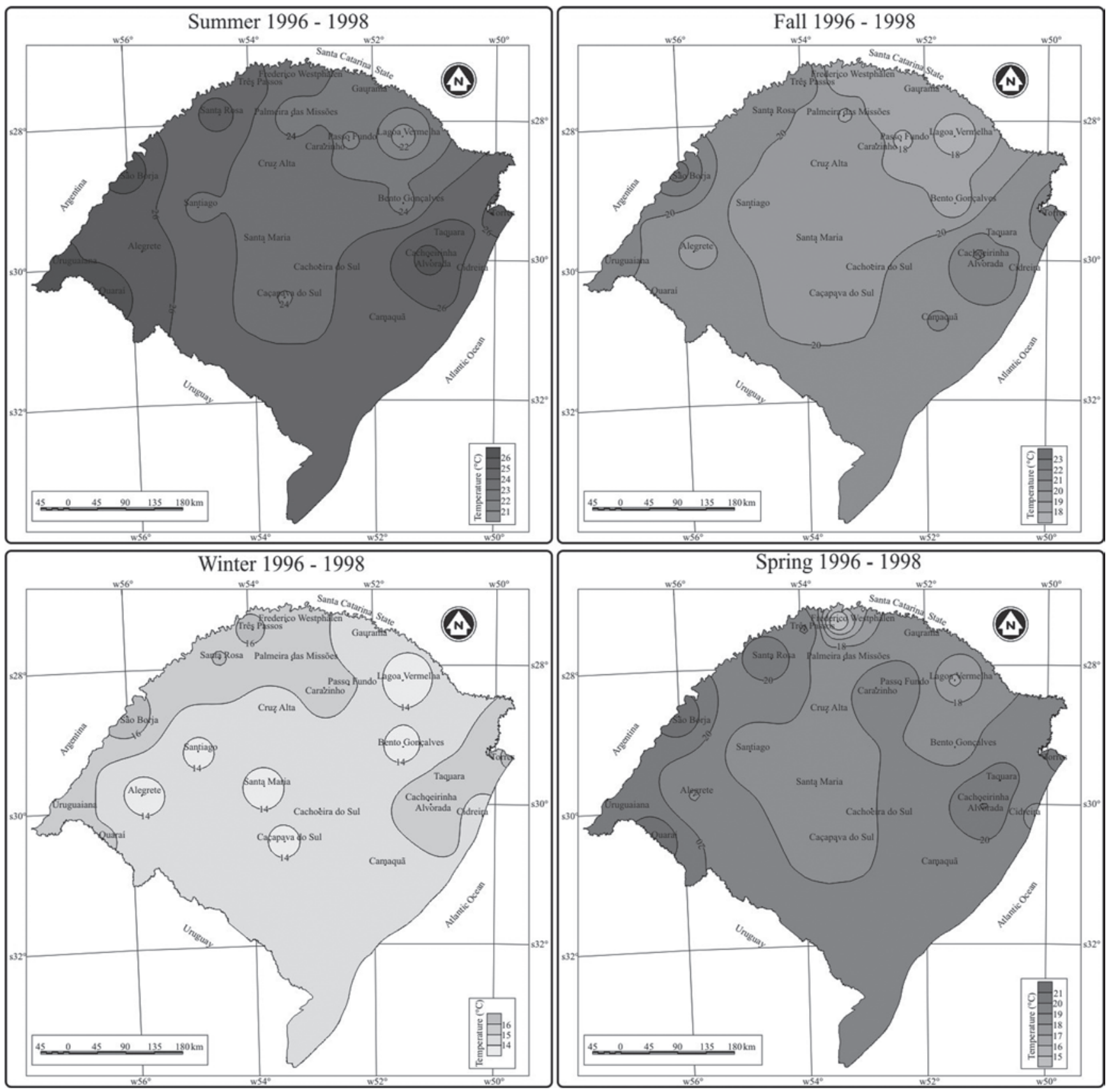

Fig. 1. Mean water temperature in several cities of the state of Rio Grande do Sul from 1996 to 1998 (Source CORSAN/RS). 
Caçapava, Cachoeirinha, Cachoeira do Sul, Camaquã, Cidreira, Cruz Alta, Carazinho, Frederico Westphalen, Gaurama, Lagoa Vermelha, Palmeira das Missões, Passo Fundo, Quaraí, São Borja, Santa Maria, Santiago, São Marcos, Santa Rosa, Três Passos, Taquara, Torres, and Uruguaiana), were kindly provided by CORSAN-RS. These mean monthly austral temperature data were used to calculate means of summer (JanuaryMarch), fall (April_-June), winter (July_-September) and spring (October-December) of every three years. The maps of water temperature were produced with software Surfer 8
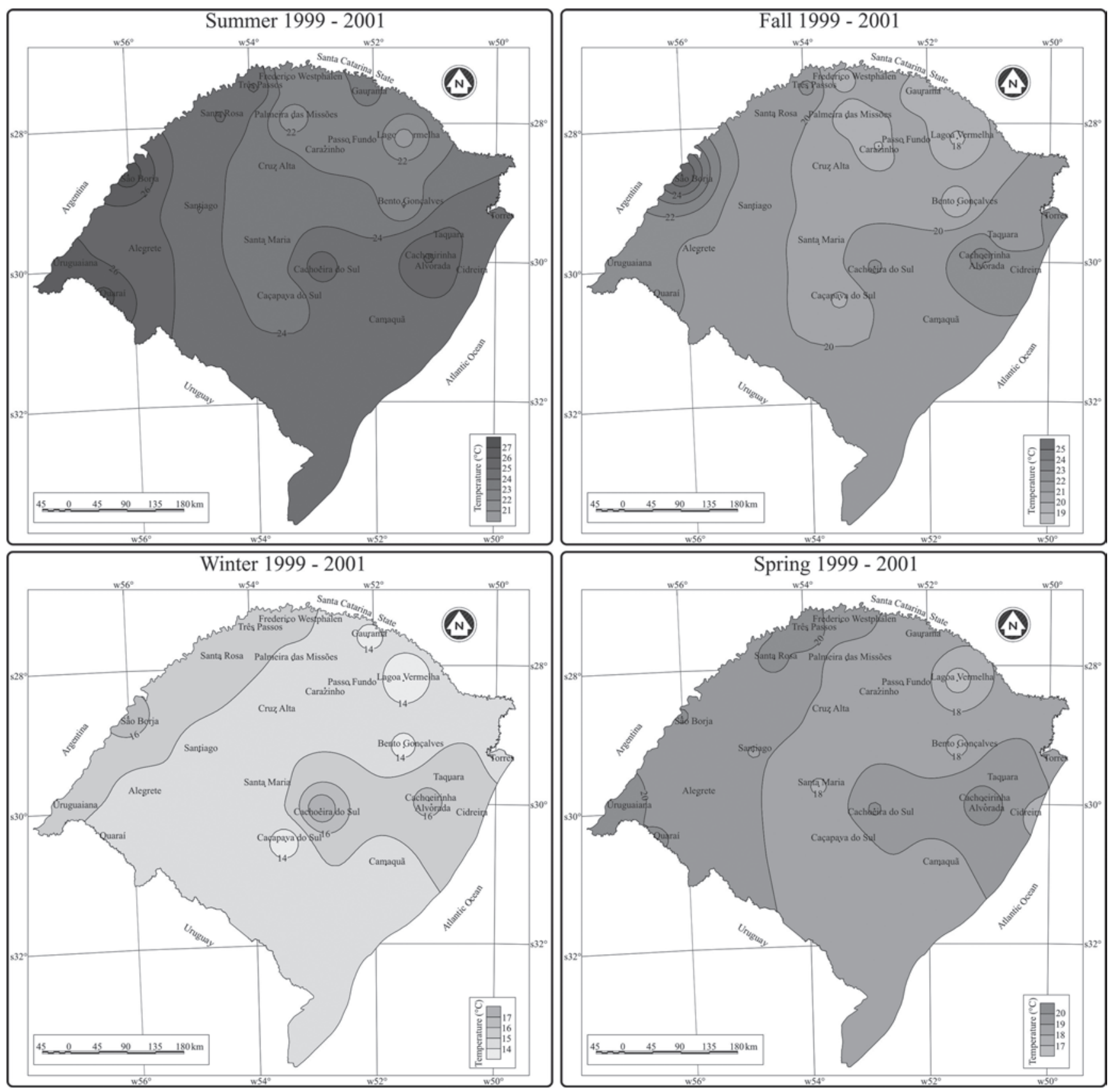

Fig. 2. Mean water temperature in several cities of the state of Rio Grande do Sul from 1999 to 2001 (Source CORSAN/RS). 
temperature range, from 16 to $28^{\circ} \mathrm{C}$ (Fig. 3a). The lowest water temperature in the summer of this period occurred from the central to north and northwest regions (Figs. 1a, 2a and 3a). The lowest mean monthly temperature in the summer was recorded in Passo Fundo $\left(12^{\circ} \mathrm{C}\right)$ and the highest in Alegrete $\left(32^{\circ} \mathrm{C}\right)$.

The mean water temperature in the fall from 1996 to 2004 remained in the $17-25^{\circ} \mathrm{C}$ range and the lowest temperatures found in this period were in the central (Caçapava do Sul, Cachoeira do Sul, Santiago, and Santa Maria) and north
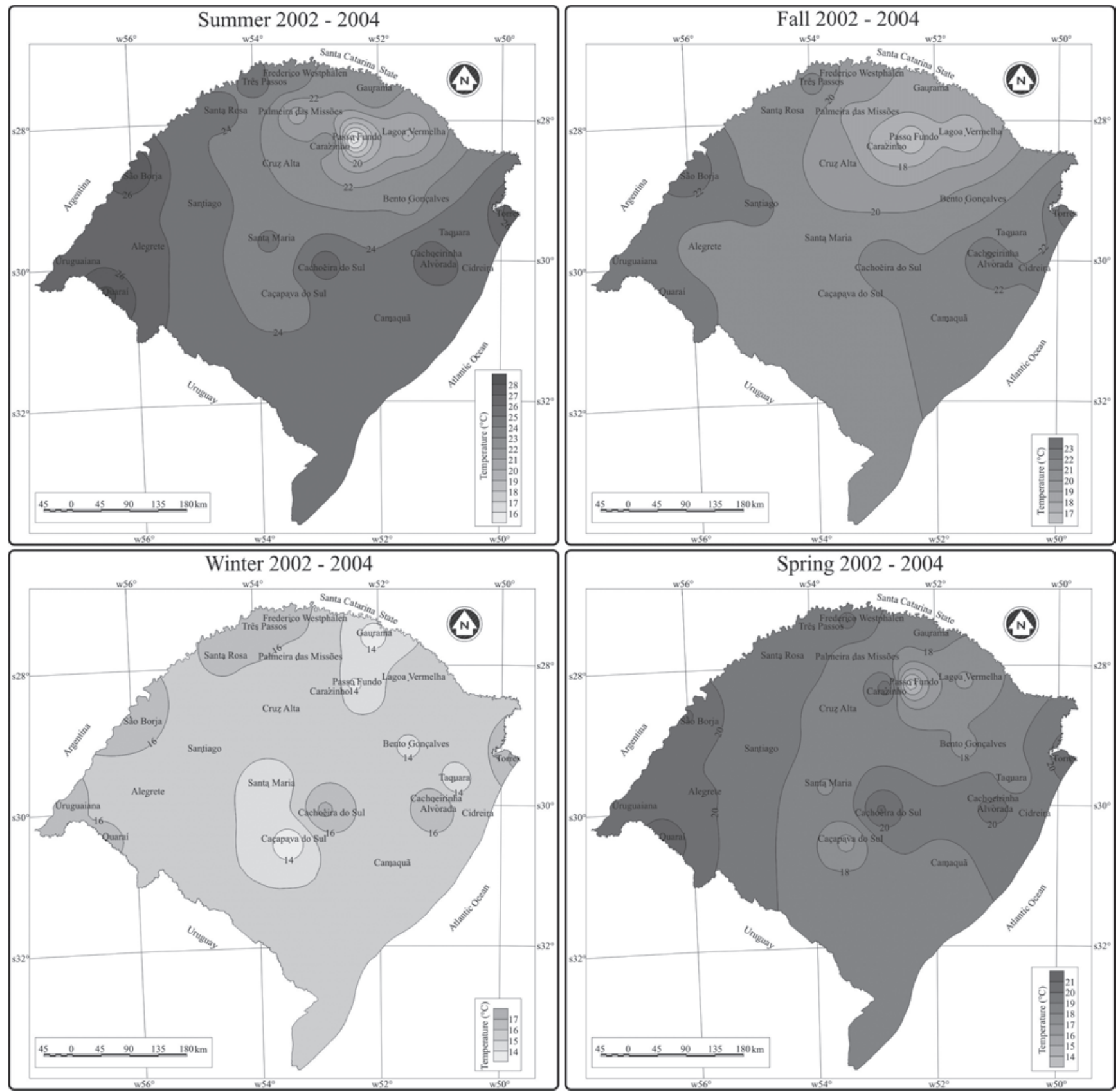

Fig. 3. Mean water temperature in several cities of the state of Rio Grande do Sul from 2002 to 2004 (Source CORSAN/RS). 
Table 1. Temperature ranges $\left({ }^{\circ} \mathrm{C}\right)$ for freshwater fishes raised in Brazil. * Water temperature from the natural habitat and proposed by the authors (growth experiments not performed). ND - Not determined.

\begin{tabular}{|c|c|c|c|c|}
\hline Species & $\begin{array}{l}\text { Best temperature for } \\
\text { growth }\end{array}$ & $\begin{array}{l}\text { Temperature limits } \\
\text { for growth }\end{array}$ & $\begin{array}{l}\text { Lethal temperatures } \\
\text { (lower and upper) }\end{array}$ & Reference \\
\hline Arapaima gigas & 24 to $31^{*}$ & ND & ND & Pereira-Filho \& Roubach (2005) \\
\hline Astyanax altiparanae & 24 to 28 & Below 20 - ND & ND & Porto Foresti et al. (2005) \\
\hline Brycon amazonicus & 28 & $18-32$ & ND & Gomes \& Urbinati (2005) \\
\hline Brycon orbignyanus & 24 to 28 & ND & ND & Ceccarelli et al. (2005) \\
\hline Carps & 28 & $4-35$ & ND & Ribeiro (2001) \\
\hline Colossoma macropomum & 25 to $34 *$ & ND & 18 and ND & Araújo-Lima \& Gomes (2005) \\
\hline Geophagus brasiliensis & ND & ND & 9 and 36 & Rantin (1980); Rantin \& Petersen (1985) \\
\hline Hoplias malabaricus & 22 to 26 & ND & ND & Matkovic \& Pisanó (1989) \\
\hline Ictalurus punctatus & 29 to 30 & 18 - ND & ND & Ribeiro (2001) \\
\hline Odontesthes bonariensis & 23 & ND - 26 & ND & Sampaio \& Piedras (2005) \\
\hline Oncorhynchus mykiss & 13 to 17 & $10-20$ & 0 and 25 & Logan \& Johnston (1992) \\
\hline Oreochromis niloticus & 26 to 28 & $24-32$ & 12 and ND & Cyrino \& Conte (2004) \\
\hline Piaractus brachypomus & 27 & $25-32$ & 22 and ND & Vásquez-Torres (2005) \\
\hline Piaractus mesopotamicus & 23 to 29 & below 22 - ND & 16 and ND & Mendonça et al. (1988) Urbinati \& Gonçalves (2005) \\
\hline Pseudoplatystoma corruscans & 28 & $21-36$ & 9 and ND & Campos (2005) \\
\hline Pterophyllum scalare & 24 to 26 & 20 - ND & 15 and ND & Chellappa (2005) \\
\hline Rhamdia quelen & 24 & ND & 3 and 32 & Chipari Gomes et al. (1999); Piedras et al. (2004) \\
\hline Salminus brasiliensis & ND & $18-\mathrm{ND}$ & ND & Weingartner \& Zaniboni Filho (2005) \\
\hline
\end{tabular}

up to the north of the state (Frederico Westphalen, Palmeira das Missões, Passo Fundo, Carazinho, Três Passos, and Santa Rosa), bordering the Uruguay River (Figs. 1c, 2c and 3c). The lowest mean monthly temperature $\left(10^{\circ} \mathrm{C}\right)$ was recorded in Alegrete, Bento Gonçalves, Passo Fundo, Quaraí, Santa Maria, and São Marcos and the highest $\left(20^{\circ} \mathrm{C}\right)$ was observed in Passo Fundo and Três Passos.

The mean water temperature in spring from 1996 to 2004 was in the $14-21^{\circ} \mathrm{C}$ range, and in this season from 1999 to 2001 there was a lower variation of temperature, from 17 to $20^{\circ} \mathrm{C}$ (Figs. 1d, 2d and 3d). The lowest mean monthly water temperature in this period $\left(9^{\circ} \mathrm{C}\right)$ was registered in Frederico Westphalen and Passo Fundo, and the highest $\left(32^{\circ} \mathrm{C}\right)$ was measured in Quaraí.

\section{Discussion}

In southern Brazil the climate is subtropical with a wide water temperature range (up to $32^{\circ} \mathrm{C}$ in summer and below $9^{\circ} \mathrm{C}$ in some cities in winter). The north and northeast regions of Rio Grande do Sul are located in the highest altitudes and usually the lowest air temperature. Consequently, these regions also present the lowest water temperatures (Machado, 1950; Sartori, 2003).

Fishes have cutaneous and hypothalamic thermal sensors to detect water temperature change, but as ectothermic animals, they rely essentially on behavioral thermoregulation (Bicego et al., 2007). Metabolism of freshwater fishes in dependent of temperature acclimation: an increase in water temperature induces an increase on oxygen consumption (Debnath et al., 2006) and ATP hydrolysis in some tissues (Lermen et al., 2005). The thermal range of fishes from temperate waters is around 4 to $25^{\circ} \mathrm{C}$, much wider than tropical ( 25 to $28^{\circ} \mathrm{C}$ ) and cold water fish $\left(4\right.$ to $15^{\circ} \mathrm{C}$ ) (Parker \& Davis, 1981; Frascá-Scorvo et al., 2001). Native species such as silver catfish (Rhamdia quelen), dourado (Salminus brasiliensis), traíra (Hoplias malabaricus), and exotic species such as common carp (Cyprinus carpio), grass carp

Table 2. Maximum, minimum and ideal temperature range $\left({ }^{\circ} \mathrm{C}\right)$ for reproduction and egg incubation for different fish species. ND - Not determined.

\begin{tabular}{lllll}
\hline Species & $\begin{array}{l}\text { Limit } \\
\text { min. }\end{array}$ & $\begin{array}{l}\text { Limit } \\
\text { max. }\end{array}$ & Ideal & Reference \\
\hline Astyanax altiparanae & 20 & ND & 26 & Porto-Foresti et al., 2005. \\
Brycon orbignyanus & ND & ND & $26-28$ & Ceccarelli et al. (2005) \\
Carps & 18 & ND & 25 & Parra (2005) \\
Colossoma macropomum & ND & 30 & $27-29$ & Lovskin (1980) \\
Leporinus elongatus & ND & ND & $24-29$ & Reynalte-Tataje et al. (2001); Reynalte-Tataje \& Zaniboni Filho (2005) \\
Rhamdia quelen & 17 & ND & $22-27$ & Baldisserotto \& Radünz Neto (2005) \\
Odontesthes bonariensis & 13 & ND & $15-20$ & Sampaio \& Piedras (2005) \\
Oncorhynchus mykiss & 5 & ND & $10-12$ & Springate et al. (1984); Puccini (2005) \\
Piaractus mesopotamicus & ND & ND & $22-28$ & Urbinati \& Gonçalves (2005) \\
Prochilodus sp. & ND & 29 & $24-26$ & Nakatani et al. (2001) \\
Pseudoplatystoma corruscans & ND & ND & $26-28$ & Pulido \& Benitez (2005) \\
Pterophyllum scalare & ND & ND & $24-26$ & Chellappa (2005) \\
Salminus brasiliensis & ND & ND & $26-28$ & Weingartner \& Zaniboni Filho (2005) \\
\hline
\end{tabular}


(Ctenopharyngodon idella), bighead carp (Aristichthys nobilis) and silver carp (Hypophtalmichthys molitrix) can survive a wide range of water temperatures (Table 1 ) and are, therefore, well adapted to the low winter water temperatures in southern Brazil.

Northern Brazil has a tropical climate and throughout the year mean water temperatures are above $24^{\circ} \mathrm{C}$. Some species that live in these ecosystems such as pacu (Piaractus mesopotamicus), pirarucu (Arapaima gigas), tucunaré (Cichla sp.), pirapitinga (Piaractus brachypomus), surubim (Pseudoplatystoma coruscans) and tambaqui (Collossoma macropomum) are not able to tolerate temperatures lower than $16^{\circ} \mathrm{C}$, which usually occur in the coldest months in southern Brazil (Table 1). Pacu and surubim are cultivated in southern Brazil (specimens of surubim are bought from producers from the Pantanal Basins and not collected from the rivers of southern Brazil), but their growth and reproduction are affected due to lower water temperatures, and usually mortality of these fishes occurs in the coldest months ( Araújo-Lima \& Gomes, 2005; Urbinati \& Gonçalves, 2005). In juvenile Nile tilapia (Oreochromis niloticus), temperatures below 16 to $18^{\circ} \mathrm{C}$ inhibit the immune response and reduce growth rates (Cyrino $\&$ Conte, 2004). Consequently, the system for tilapia production requires the use of plastic greenhouses in a tunnel with a rigorous control of the water temperature as suggested by Zimmermann \& Fitzsimmons (2004). Similar systems may be used for other tropical species, but as this system increases the production cost an economical analysis of the viability of this procedure in southern Brazil is advised. On the other hand, as the best growth rate of rainbow trout (Oncorhynchus mykiss) is between 15 and $17^{\circ} \mathrm{C}$ (Logan \& Johnston, 1992), this species can be raised only in regions of higher altitude in Rio Grande do Sul, and its growth rate probably will be reduced in the warmer months.

The spawning of most freshwater fishes is directly related to the water temperature (Ferraz de Lima et al., 1984). Carps tolerate a wide temperature range, but gonadal maturation can be significantly retarded when exposed to temperatures below $16^{\circ} \mathrm{C}$ (Woynarovich \& Horváth, 1984), and induced spawning after administration of pituitary carp extract only occurs when fish are maintained in water with temperature above $18^{\circ} \mathrm{C}$ (Table 2). However, for most species raised in Brazil the best temperature range for reproduction is 24-28 ${ }^{\circ} \mathrm{C}$ (Table 2), which is slightly higher than the mean temperatures observed in the spring of the state of Rio Grande do Sul. Consequently, fish farmers have to postpone the induced spawning of these species or use reproducers in non-optimal conditions.

It can be concluded that water temperature in the state of Rio Grande do Sul should be considered in the choice of fish species to be raised. Native species from this state (silver catfish, traíra, dorado) and carps require a temperature range suitable for cultivation, but pacu, matrinxã, surubim (originated from Pantanal Basin), pirapitinga, pirarucu, tambaqui (Amazon basin) and tilapia are not recommended species, as a high mortality is very likely to occur in the colder months.

\section{Acknowledgments}

B. Baldisserotto and L.O. Garcia received a CNPq and CAPES fellowships, respectively. The authors thank Dr. Nélio B. Barros, from Portland State University for English corrections.

\section{Literature cited}

Arana, L. V. 2004. Princípios Químicos de Qualidade da Água em Aqüicultura: uma Revisão para Peixes e Camarões. Florianópolis, UFSC, 2. ed., 231p.

Araújo-Lima, C. A. R. M. \& L. C. Gomes. 2005. Tambaqui (Colossoma macropomum). Pp. 175-193. In: Baldisserotto, B. \& L. C. Gomes. (Eds.). Espécies Nativas para Piscicultura no Brasil. Santa Maria, UFSM, 470p.

Baldisserotto, B. 2002. Fisiologia de Peixes Aplicada à Piscicultura. Santa Maria, UFSM, 212p.

Baldisserotto, B. (In Press). Piscicultura de água doce no Rio Grande do Sul: situação atual, problemas e propostas para o futuro.

Baldisserotto, B. \& J. Radünz Neto. 2005. Jundiá (Rhamdia sp.). Pp. 303-325. In: Baldisserotto, B. \& L. C. Gomes. (Eds.). Espécies nativas para piscicultura no Brasil. Santa Maria, UFSM, 470p.

Bicego, K. C., R. C. H. Barros \& L. G. S. Branco. 2007. Physiology of temperature regulation: Comparative aspects. Comparative Biochemistry and Physiology A, 147: 616-639.

Campos, J. L. 2005. O cultivo do pintado, Pseudoplatystoma corruscans (Spix e Agassiz, 1829). Pp. 327-344. In: Baldisserotto, B. \& L. C. Gomes. (Eds.). Espécies Nativas para Piscicultura no Brasil. Santa Maria, UFSM. 470p.

Ceccarelli, P. S., J. A. Senhorini \& R. F. Rego. 2005. Piracanjuba, Brycon orbignyanus (Valenciennes, 1849). Pp. 121-145. In: Baldisserotto, B. \& L. C. Gomes. (Eds.). Espécies Nativas para Piscicultura no Brasil. Santa Maria, UFSM, 470p.

Chellapa, S. 2005. Acará bandeira (Pterophyllun scalare). Pp. 393402. In: Baldisserotto, B. \& L. C. Gomes (Eds.). Espécies Nativas para Piscicultura no Brasil. Santa Maria, UFSM, 470p.

Chipari Gomes, A. R., L. C., Gomes \& B. Baldisserotto. 1999. Lethal temperatures for silver catfish, Rhamdia quelen, fingerlings. Journal of Applied Aquaculture, 9(4): 11-21.

Cyrino, J. E. P. \& L. Conte. 2004. Tilapicultura em gaiolas: Produção e economia. Anais AquaCiência, Vitória, ES. p. 151-171.

Debnath, D., A. K. Pal, N. P. Sahu, K. Baruah, S. Yengkokpam, T. Das \& S. M. Manush. 2006. Thermal tolerance and metabolic activity of yellowtail catfish Pangasius pangasius (Hamilton) advanced fingerlings with emphasis on their culture potential. Aquaculture, 258: 606-610.

Ferraz de Lima, J. A., G. Barbieri \& J. R. Verani. 1984. Período de reprodução, tamanho e idade da primeira maturação gonadal do pacu, Colossoma mitrei, em ambiente natural (Rio Cuiabá, Pantanal do Mato Grosso). Anais Simpósio Brasileiro de Aqüicultura III. São Carlos, SP. p. 477-497.

Frascá-Scorvo, C. M. D., D. J. Carneiro \& E. B. Malheiros. 2001. Feeding behaviour of "matrinxã" (Brycon cephalus) during the period of lower temperatures. Boletim do Instituto de Pesca de São Paulo, 27(1): 1-5.

Gomes, L. C. \& E. C. Urbinati. 2005. Matrinxã (Brycon amazonicus). In: Baldisserotto, B. \& L. C. Gomes. (Eds.). Espécies Nativas para Piscicultura no Brasil. Santa Maria, UFSM, 470p.

Hazel, J. R. Thermal Biology. 1993. Pp.427-467. In: Evans, D.H. 
The Physiology of Fishes. Boca Raton: CRC Press. 592 p.

Laevastu, T. \& M. Hayes. 1984. Pp.5-23. Effects of environmental factors on fish. In: Fisheries, Oceanography and Ecology. London, Fishing New Books Ltd.

Lermen, C. L., V. L. P. Vieira, M. R. C. Schetinger, R. Lappe, C. R. Gioda, M. R. Crestani, B. Baldisserotto \& V. M. Morsch. 2005. ATP, ADP and AMP dephosphorylation in membrane fractions of Rhamdia quelen exposed to different temperatures. Fish Physiology and Biochemistry, 31: 295-301.

Logan, S. H. \& W. E. Johnston. 1992. Economics of commercial trout production. Aquaculture, 100:25-46.

Lovshin, L. L. 1980. Situación del cultivo de Colossoma sp. en Sud América. Revista Latinoamericana de Acuicultura, 5: 27-32.

Machado, F. P. 1950. Contribuição ao estudo do clima no Rio Grande do Sul. Rio de Janeiro, IBGE, 91p.

Matkovic, M. \& A. Pisanó. 1989. Estúdio macro y microscópico del desarrollo de Hoplias malabaricus (Pisces, Erythrinidae). II: fase postlarval. Revista Brasileira de Biologia, 49(2): 571582.

Mendonça, J. O. J., V. A. Ferrari, L. A. Gaspar \& M. B. Camargo. 1988. Monocultivo de pacu Colossoma mitrei em uma propriedade particular. Boletim Técnico do CEPTA, 1(1): 29-35.

Nakatani, K., A. A. Agostinho, G. Baumgartner, A. Bialetzki, P. V. Sanches, M. C. Makrakis \& C. S., Pavanelli. 2001. Ovos e Larvas de Peixes de Água Doce: Desenvolvimento e Manual de Identificação. Maringá, EDUEM, 378 p.

Parker, N. \& K. Davis. 1981. Requirements of warmwater fish. Pp.21-28. In: Allen, L. \& E. Kinney (Eds.). Proceedings of the bioengineering symposium for fish culture. Bathesda, Maryland, USA, Fish culture section of the American Fisheries Society.

Parra, M. A. L. 2005. Aspectos fundamentales del manejo reproductivo de la carpa común (Cyprinus carpio Linnaeus, 1758) em cautiverio. Pp.165-174. In: Daza, P. V., M. A. L. Parra \& A. I. S. Ochoa. Reprodución de Peces en el Trópico. Bogotá, INCODER/Universidad Nacional de Colombia, 246p.

Pereira-Filho, M. \& R. Roubach. 2005. Pirarucu (Arapaimas gigas). In: Baldisserotto, B. \& L. C. Gomes. (Eds.). Espécies Nativas para Piscicultura no Brasil. Santa Maria, UFSM, 470p.

Piedras, S. R. N., P. R. R. Moraes \& J. L. O. F. Pouey. 2004. Crescimento de juvenis de jundiá (Rhamdia quelen), de acordo com a temperatura. Boletim do Instituto de Pesca de São Paulo. 30(2):177-182.

Porto-Foresti, F., R. B. Castilho-Almeida \& F. Foresti. 2005. Pp. 105-120. In: Baldisserotto, B. \& L. C. Gomes (Eds.). Espécies Nativas para Piscicultura no Brasil. Santa Maria, UFSM, 470p.

Puccini, R. R. 2005. Manejo reproductivo em cautiverio de la trucha arco íris (Oncorhynchus mykiss Walbaum, 1792). Pp.123-145. In: Daza, P. V., M. A. L. Parra \& A. I. S. Ochoa. Reprodución de Peces en el Trópico. Bogotá, INCODER/Universidad Nacional de Colombia, 246p.

Pulido, J. A. R. \& H. O. M. Benítez. 2005. Reprodución y manejo de silúridos en cautiverio. Pp.105-122. In: Daza, P. V., M. A. L. Parra \& A. I. S. Ochoa. Reprodución de Peces en el Trópico. Bogotá, INCODER/Universidad Nacional de Colombia, 246p.
Rantin, F. T. 1980. Temperaturas letais do acará Geophagus brasiliensis (Quoy \& Gaimard, 1824 - Pisces, Cichlidae). Boletim de Fisiologia Animal, USP, 4: 9-33.

Rantin, F. T. \& J. A. Petersen. 1985. Thermal tolerance of South American Cichlidae, Geophagus brasiliensis. Revista de Hydrobiologia Tropical, 18(3): 221-226.

Reynalte-Tataje, D. R. \& E. Zaniboni Filho. 2005. Cultivo do gênero Leporinus. Pp. 81-104. In: Baldisserotto, B. \& L. C. Gomes. (Eds.). Espécies Nativas para Piscicultura no Brasil. Santa Maria, UFSM. 470p.

Reynalte-Tataje, D. A., E. Zaniboni Filho \& B. Muelbert. 2001. Stage of the embryonic development of the piavuçu Leporinus macrocephalus (Garavello \& Britski, 1988). Acta Scientarium, 23(4): 823-827.

Ribeiro, R. P. 2001. Espécies exóticas. Pp. 91-121. In: Moreira, H. L. M., L. Vargas, R. P. Ribeiro \& S. Zimmermann (Eds.). Fundamentos da Moderna Aquicultura. Canoas: ULBRA. 199p.

Sampaio, L. A. \& S. R. N. Piedras. 2005. Cultivo do peixe-rei marinho, Odontesthes argentinensis, e de água doce, Odontesthes bonariensis. Pp. 345-361. In: Baldisserotto, B. \& L. C. Gomes. (Eds.). Espécies Nativas para Piscicultura no Brasil. Santa Maria, UFSM. 470p.

Sartori, M. G. B. 2003. A dinâmica do clima do Rio Grande do Sul: Indução empírica e conhecimento científico. Revista Terra Livre, 1(20): 27-49.

Springate, J. R. C., N. Bromage, J. A. K. Elliot \& D. L. Hudson. 1984. The timing of ovulation and stripping and their effects on the rates of fertilization, and survival to eying, hatching and swim-up in the rainbow trout (Salmo gairdneri R.). Aquaculture, 43: 313-322.

Urbinati, E. C. \& F. D. Gonçalves. 2005. Pacu (Piaractus mesopotamicus). Pp. 225-256. In: Baldisserotto, B. \& L.C. Gomes (Eds.). Espécies Nativas para Piscicultura no Brasil. Santa Maria, UFSM. 470p.

Vásques-Torres, W. 2005. A pirapitinga, reprodução e cultivo. Pp. 203-223. In: Baldisserotto, B. \& L.C. Gomes (Eds.). Espécies Nativas para Piscicultura no Brasil. Santa Maria, UFSM, 470p. Weingartner, M. \& E. Zaniboni Filho. 2005, Dourado. Pp. 257-286. In: Baldisserotto, B. \& L. C. Gomes. (Eds.). Espécies Nativas para Piscicultura no Brasil. Santa Maria, UFSM, 470p.

Woynarovich, E. \& L. Horváth. 1984. The artificial propagation of warm-water finfish - A manual for extension. Fisheries Technical Papers (FAO). 183 p.

Zimmermann, S. \& K. Fitzsimmons. 2004. Pp. 239-266. Tilapicultura intensiva. In: Cyrino, J. E. P., E. C. Urbinati, D.M. Fracalossi \& C. Castagnolli.(Eds.). Tópicos Especiais em Piscicultura de Água Doce Tropical Intensiva. São Paulo, TecArt, 533 p.

Accepted February 2008 Published June 28, 2008 